IQTISHODUNA

Vol. 16 (2), 2020

P-ISSN: 1829-524X, E-ISSN: 2614-3437

\title{
Implementasi Variabel Makro: Zakat, Infak Dan Shodaqah (Zis) Pada Pelaku Ekonomi Kreatif Makanan Siap Saji Berbasis Singkong
}

\author{
Masyhuri \\ Universitas Islam Malang, Indonesia \\ masyhuri.machfudz@unisma.ac.id
}

\begin{abstract}
The purpose of this study is the impact of macro variables on zakat, shodaqah and infaq (Zis) on economic growth (aggregate demand; AD). The initial impact is controlled from the macro variables of consumption, investment, saving and government expenditure. This study is included in the basic research category because the level of technological readiness is 3 (three), namely at the laboratory level. Analysis tools are carried out using a graphical and mathematical approach. The results showed that Zis has a sectoral impact on economic growth (AD). The consumption, investment, saving, government expenditure and export variables have a positive impact on $A D$. Likewise Zis role in economic growth is positive. Whereas interest money has a negative impact. Anticipation without using interest money in the economy is done by increasing economic activity through the implementation of 14 sharia transactions. One of them is the application of qardhul-hasan to the creative economy of cassava-based fast food creative, which shows that the acceleration of the value of the currency compared to the future value can be created at $6.7 \%-10 \%$ from before. That is why Zis besides having a positive impact on economic growth (AD) also gave birth to blessing as measured through 3 indicators of blessing, namely ni'mah, sa'adah (goodness) and ziyadah (additional).
\end{abstract}

Keywords: zakat, shodaqah, infaq and economic growth.

Abstrak: Tujuan penelitian ini dampak variabel makro zakat, shodaqah dan infak (Zis) pada pertumbuhan ekonomi(agregrat demand;AD). Awal dampak ini dikontrol dari variabel makro konsumsi, investasi, tabungan (saving) dan pengeluaran pemerintah. Penelitian ini termasuk katagori penelitian dasar karena tingkat kesiapan teknologinya 3 (tiga), yaitu pada level laboratorium. Alat analisis dilakukan dengan pendekatan grafik dan matematis. Hasil penelitian menunjukkan bahwa Zis secara sektoral berdampak pada pertumbuhan ekonomi (AD). Variabel-variabel konsumsi, investasi, saving, pengeluaran pemerintah dan ekspor berdampak positif pada AD. Demikian juga peran Zis-pun pada pertumbuhan ekonomi adalah positif. Sedangkan bunga uang berdampak negatif. Antisipasi tanpa menggunakan bunga uang dalam perekonomian dilakukan dengan peningkatan aktivitas ekonomi melalui implementasi 14 transaski syari'ah. Salah satu diantaranya adalah aplikasi qardhulhasan pada pelaku ekonomi kreatif makanan siap saji berbasis singkong, yang menunjukkan bahwa akselerasi nilai mata uang saat ini (the value of the currency)dibandingkan nilai yang akan dating (future currency values) dapat diciptakan sebesar 6,7\%-10\% dari sebelumnya. Sebab itulah Zis disamping berdampak positif pada pertumbuhan ekonomi (AD) juga melahirkan keberkahan yang diukur melalui 3 indikator keberkahan, yaitu ni'mah, sa'adah (kebaikan) dan ziyadah (tambahan).

Kata kunci: zakat, shodaqah, infak dan pertumbuhan ekonomi. 


\section{Cara mencitasi:}

Masyhuri (2020). Implementasi Variabel Makro Zakat, Infak Dan Shodaqah (Zis) Pada Pelaku Ekonomi Keratif Makanan Siap Saji Berbasis Singkong. Iqtishoduna, 16 (2), 191-202.

\section{Pendahuluan}

Variabel-variabel ekonomi berupa konsumsi, tabungan, investasi, pajak, tarif pajak, pembayaran transfer, pengeluaran pemerintah, ekspor dan import, pertumbuhan ekonomi, dan sebagainya. Besarnya pengaruh variabel konsumsi rumah tangga (counsumption, C) dan tabungan (saving, S), investasi (invest, I), partisipasi pemerintah dalam aktivitas ekonomi yang berupa government expenditure (G) dan lain-lain pada pertumubuhan ekonomi adalah positif.

Secara konsep peranan dari variabel-varibel makro diatas mendorong semaraknya aktivitas ekonomi, sebab berawal dari penjumlahan pengeluaran rumah tangga menjadi pengeluaran wilayah terdiri dari dua variabel konsumsi dan investasi, pada satu sisi. Sisi lain penjumlahan pendapatan rumah tangga terdiri dari konsumsi dan tabungan juga menjadi pendapatan wilayah. Secara alami antara pengeluaran (expenditure, E) sama dengan pendapatan (income, Y) karena dalam realita empirik semuanya tercipta secara perpasang-pasangan sebagaimana pada QS.adz-daariyaat (49), bahwa ciptaan Allah SWT. selalu berpasang-pasangan. Atas dasar itulah ekonom selalu berpedapat bahwa aktivitas pengeluaran selalu sama dengan pendapatan sebagai pengakuan 'madzhab' ekonomi alami. 'bahasa' ekonomi lebih berpasangan-pasangan itu akan mengarah pada suatu keseimbangan (equilibrium).

Dinamisasi kondisi equilibrium akan muncul jika terjadi keterlibatan dari variabel-variabel ekonomi berupa konsumsi, tabungan, investasi, pajak, tarif pajak, pembayaran transfer, pengeluaran pemerintah, ekspor dan import, pertumbuhan ekonomi, dan sebagainya. Besarnya pengaruh variabel konsumsi rumah tangga (counsumption, C) dan tabungan (saving, S), investasi (invest, I), partisipasi pemerintah. Demikian juga variabel zakat, infak dan shodaqah (Zis) mempunyai kontribusi yang nyata pada posisi equilibrium. Seperti yang diungkapkan oleh Siami dan Hudson (2019); Hany

192 | IQTISHODUNA Vol. 16 (2), 2020

http://ejournal.uin-malang.ac.id/index.php/ekonomi 
dan Islamiyati (2020) bahwa Selain pertumbuhan ekonomi, inflasi merupakan salah satu indikator ekonomi makro yang digunakan sebagai pengukur kestabilan ekonomi suatu negara. pertumbuhan sektor dan inflasi mempengaruhi ketimpangan pendapatan dalam jangka panjang.

Inflasi merupakan fenomena moneter dalam suatu negara dimana naik turunnya inflasi cenderung mengakibatkan terjadinya gejolak ekonomi. Disamping itu, dalam perspektif ekonomi Islam juga terdapat faktor yang mempengaruhi pertumbuhan ekonomi yaitu penyaluran dana zakat, infak dan sedekah (ZIS) (Anggraini dan Widiastuti, 2017). Untuk itulah menarik untuk diteliti seberapa jauh dampak variabel-variabel makro dan variabel Zis mempunyai peran dalam aktivitas ekonomi (pertumbuhan ekonomi secara agregat, AD), sekaligus dianalisis dengan membandingkan bunga uang berdampak pada pertumbuhan ekonomi.

\section{Landasan Teori}

Masyhuri (2012) disebutkan bahwa pada perekonomian sederhana ada dua sektor, yaitu sektor rumah (househoud) dan sektor perusahaan (firm). Pada perekonomian dua sektor terdiri dari dua fihak yaitu rumah tangga dan perusahaan - rumah tangga yang bekerja pada perusahaan mendapatan pendapatan (upah) dan pendapatan tersebut dibelanjakan untuk beli barang dan jasa yang disediakan oleh perusahaan, besarnya nilai barang dan jasa yang dikonsumsi rumah tangga sama dengan pedapatan yang diterima rumah tangga, dengan demikian pendapatan (Income, $\mathrm{Y}$ ), $\quad \mathrm{Y}=\mathrm{C}+\mathrm{S}$.

Pengeluaran (expenditure, E), E=C+I. Pendapatan (Y) digunakan sebagian untuk konsumsi rumah tangga (counsumption, C) dan sisanya untuk tabungan (saving, S). Sedangkan pengeluaran (E) digunakan untuk pengeluaran konsumsi rumah tangga (C) dan sebagaian untuk investasi (invest, I) dari perusahaan.

Atas dasar pengeluaran sama dengan pendapatan tersebut, maka perekonomian dikatakan seimbang apabila $S=I$ yang berasal dari persamaan Y=E. Dari masing-masing variabel di atas, maka dapat jelaskan bahwa konsumsi tergantung pada pendapatan $\mathrm{C}=\mathrm{f}(\mathrm{Y})$ artinya besar kecil konsumsi tergantung pada pendapatan. Berapa ketergantungannya?, maka untuk menjawab ini model tersebut dispesifikkan modelnya menjadi regresi, yakni $\mathrm{C}=\mathrm{Co}+\mathrm{c}_{1} \mathrm{Y}$ (dapat dinterpretasikan bahwa pengaruh pendapatan terhadap konsumsi sebesar $\mathrm{c}_{1}$. $\mathrm{c}_{1}$ disebut sebagai koefisien regresi dalam fungsi konsumsi disebut juga MPC (marginal propoensity to counsumption=kecendrungan tambahan konsumsi). MPC merupakan rasio 
antara perubahan pengeluaran konsumsi dan perubahan pendapatan, secara matematis sebagai berikut:

$$
\mathrm{C}=\mathrm{Co}+\mathrm{c}_{1} \mathrm{Y}
$$

$\Delta \mathrm{C}$

$$
\mathrm{MPC}=\mathrm{c}_{1}=
$$

$\Delta \mathrm{Y}$

Untuk mencari fungsi tabungan (S), dapat dilakukan substitusi dari persamaan (2) dengan persamaan (3) dengan urutan mekanisme sebagai berikut:

$$
\begin{aligned}
\mathrm{Y} & =\mathrm{C}+\mathrm{S} \text { karena } \mathrm{C}=\mathrm{C}_{\mathrm{o}}+\mathrm{c}_{1} \mathrm{Y} \\
& =\mathrm{C}_{0}+\mathrm{c}_{1} \mathrm{Y}+\mathrm{S} \\
\mathrm{S} & =-\mathrm{C}_{0}+\left(1-\mathrm{c}_{1}\right) \mathrm{Y}
\end{aligned}
$$

dimana (1-MPC) disebut marginal propensity to save (MPS) yaitu kecendrungan tambahan untuk menabung, dan besarnya $\mathrm{MPC}+\mathrm{MPS}=1$.

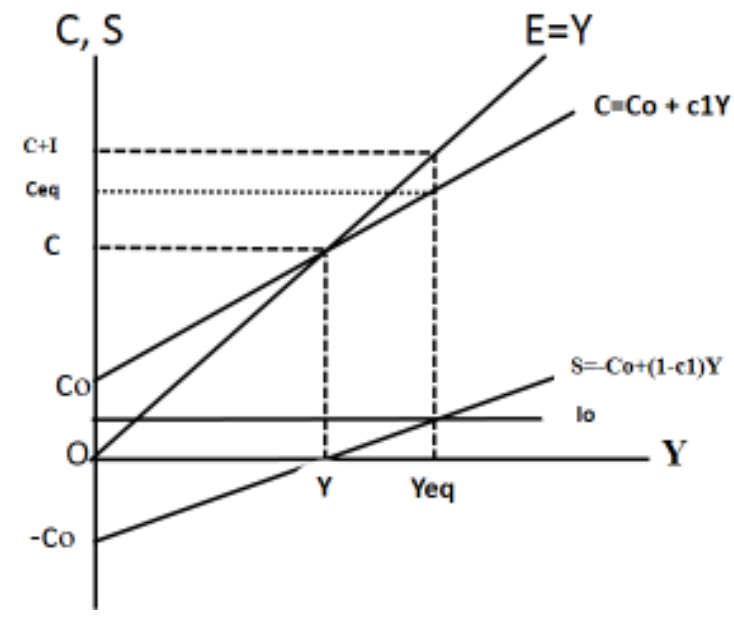

Kondisi keseimbangan $\mathrm{I}=\mathrm{S}$, apabila ada investasi otonom (outomous of invest, Io), maka cara mencari pendapatan keseimbangan pada perekonomian dua sektor ditarik garis horizontal sejajar dengan garis pendpatan (Y). $\mathrm{Y}_{\mathrm{eq}}=$ besarnya pendapatan nasional keseimbangan $\mathrm{Y}_{\mathrm{BEP}}=$ besarnya pendapatan nasional pada titik impas (break event point, BEP).

Pengeluaran investasi (I) diasumsikan konstan atau dalam persamaan merupakan variabel eksogen, yaitu variabel yang besar kecilnya ditentukan di luar system atau di luar persamaan sehingga dapat ditulis $\mathrm{I}=\mathrm{I}_{\mathrm{o}}$. Besarnya 
nilai konsumsi (C) sama dengan besarnya pendapatan (Y) disebut dengan pendapatan nasional break event point (Y $\mathrm{Y}_{\mathrm{BEP}}$ ) yang sering disebut titik impas atau bisa juga dikatakan pada saat saving mencapai nol artinya tidak ada saving sama sekali.

Kebijakan syari'ah dalam konsumsi untuk memanfaatkan pendapatannya adalah dalam kondisi yang berimbang (balance). Keseimbangan antara belanja konsumsi (C) dan produktif (investasi,I), keseimbangan antara belanja pribadi dan untuk kepentingan masyarakat dan keseimbangan antara aspek duniawi dan aspek ukhrowi. Dalam mewujukan kontribusi Zis pada pertumbuhan ekonomi, maka Masyhuri (2019) menjelaskan bahwa konsumsi dalam Islam $\left(\mathrm{C}_{\mathrm{i}}\right)$ sama dengan konsumsi dunia $\left(\mathrm{C}_{\mathrm{d}}\right)$ dan akherat $\left(\mathrm{C}_{\mathrm{a}}\right)$ atau dalam bentuk matematikanya:

$$
\begin{aligned}
& \mathrm{C}_{\mathrm{i}}=\mathrm{C}_{\mathrm{d}}+\mathrm{C}_{\mathrm{a}} \\
& \mathrm{C}_{\mathrm{d}}=\mathrm{C}_{o}+\mathrm{C}_{1} \mathrm{Y} \\
& \mathrm{C}_{\mathrm{a}}=\mathrm{C}_{\mathrm{z}}+\mathrm{C}_{\mathrm{is}}
\end{aligned}
$$

Dimana; (i) $\mathrm{C}_{\mathrm{z}}=\mathrm{zY}$ yaitu konsumsi untuk zakat besarnya $\quad \mathrm{C}_{\mathrm{z}}=0,025 \mathrm{Y}$ dan $\mathrm{C}_{\text {is }}=$ isY yaitu konsumsi untuk infak dan sedekah $\quad \mathrm{C}_{\mathrm{is}}=0,025 \mathrm{Y} . \quad$ Dari persamaan (1) (2) dan (3), diperoleh: $\mathrm{C}_{\mathrm{i}}=\mathrm{C}_{0}+\mathrm{c}_{1} \mathrm{Y}+\mathrm{zY}+\mathrm{isY}$, sehingga

$$
\mathrm{C}_{\mathrm{i}}=\mathrm{C}_{\mathrm{o}}+\left(\mathrm{c}_{1}+\mathrm{z}+\mathrm{is}\right) \mathrm{Y}
$$

\section{Metodologi Penelitian}

Jenis penelitian ini adalah eksperimen murni pada laboratorium ekonomi dengan menerapkan transaksi syari'ah baik orientasi pada pengabdian maupun pada keutungan (profiet oriented). Pelaksanaan eksperimen dilakukan sejak tahun 2015-sekarang. Bersamaan dengan ijin usaha dhearis motor (7 juli 2015).

Sumber data pada pelaku ekonomi kreatif makanan siap saji berbasis singkong dengan orientasi pada pengabdian dan pada dhearis motor adalaha yang berorientasi pada keutungan. Analisis data dilakukan secara kualitatif dan kauntitatif memakai statistik deskriptif yang melibatkan variabel Zis pada ketentuan zakat 2,5\%.

\section{Hasil Penelitian Dan Pembahasan}

Variabel-variabel yang terlibat dalam analisis dampak Zis pada pertumbuhan ekonomi (agregat demand,AD) adalah variabel konsumsi, 
tabungan, investasi, zakat, infak dan Shodaqah (Zis). Aplikasi pada angka guna memperjelas dalam melihat pengaruh zakat, infak dan shodaqah pada pertumbuhan ekonomi (Agregat Demand, AD). AD berasal dari mekanisme perekonomia dua sektor, dapat dilihat pada gambar 1 .

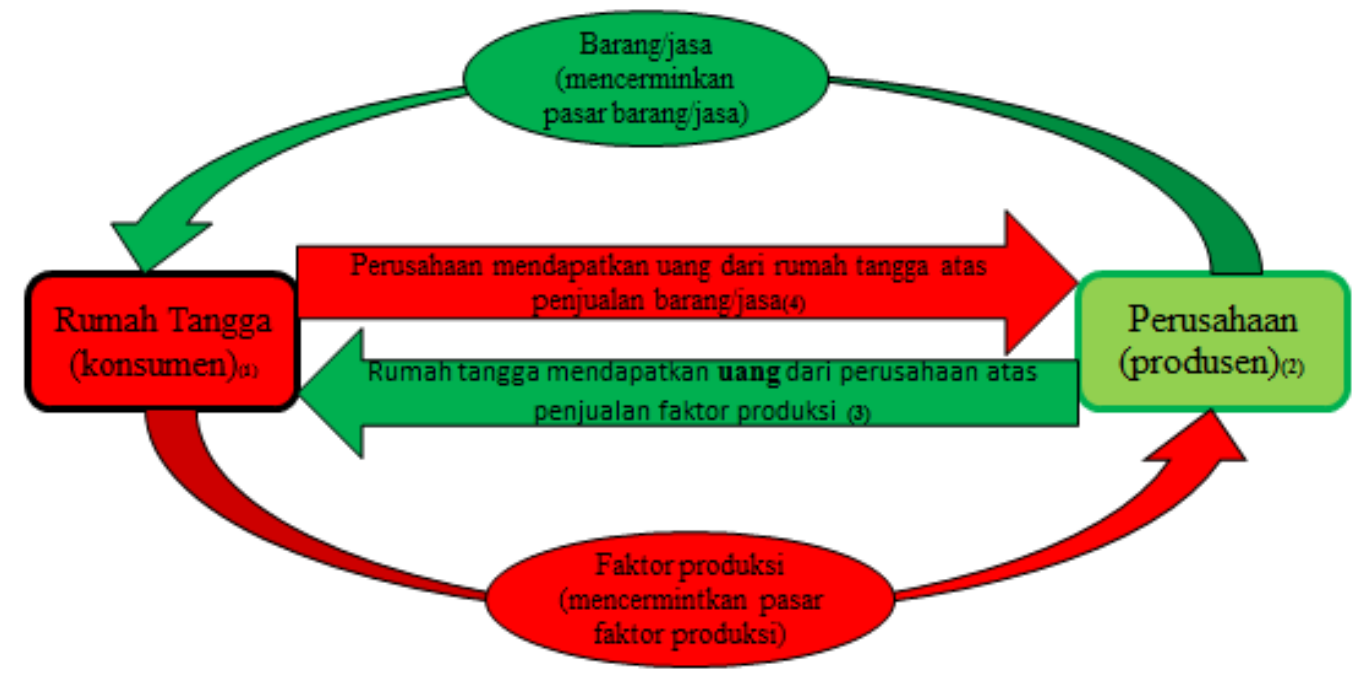

Gambar 1: pererkonomian sederhana.

Aliran uang dari rumah tangga (househould) untuk membeli produk (baju, misalnya) dari perusahaan (dan ini merupakan penerimaan perusahaan). Penerimaan perusahaan ini dipergunakan untuk untuk membayar upah pekerja dan sebagian lagi merupakan laba bagi pekerja. Jadi, pengeluaran untuk membeli baju dari rumah tangga ke perusahaan, sementara pendapatan dari perusahaan mengalir ke rumah tangga dalam bentuk upah. Rumah tangga konsumen memperoleh barang dan jasa dengan cara membeli produk dari perusahaan. Transaksi tersebut menyebabkan terjadinya arus barang dan jasa dari perusahaan ke rumah tangga konsumen melalui pasar. Transaksi tersebut menimbulkan arus uang dari rumah tangga konsumen ke produsen untuk pembayaran barang jasa yang didapatnya. Arus pembayaran itu disebut sebagai pembelanjaan masyarakat. Nilai arus barang atau jasa harus sama dengan nilai arus uang (pembelanjaan).

Berawal dari aspek mikro di atas, maka muncul ekonomi sektoral, dua, tiga dan empat sektor. Hal ini dapat dilakukan dengan angka hipotesis khususnya pada variabel pendapatan (Y) dan konsumis (C) yang tujuannya dapat mempermudah dalam melakukan analisis dampak variabel-variabel makro pada pertumbuhan ekonomi. Angka hipotesis tersbut sebagaimana pada gambar 2 . 
Implementasi Variabel Makro Zakat .....

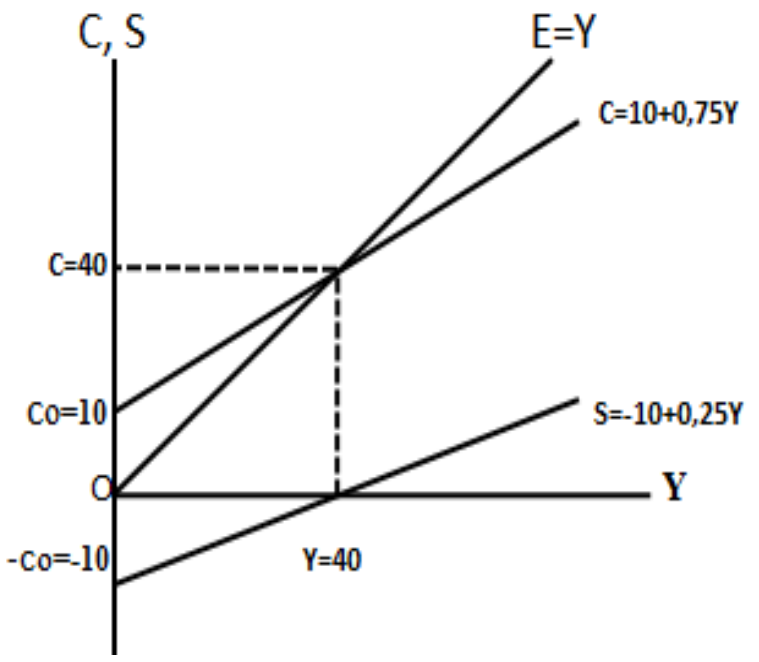

\begin{tabular}{|c|c|c|c|}
\hline $\mathrm{Y}$ & C & $\mathrm{S}$ & $\Delta C / \Delta \mathrm{Y}$ \\
\hline 侟 & 10 & -10 & 0,75 \\
\hline 10 & 17,5 & $-7,5$ & 0,75 \\
\hline 20 & 25 & -5 & 0,75 \\
\hline 30 & 32,5 & $-2,5$ & 0,75 \\
\hline 40 & 40 & 0 & 0,75 \\
\hline 50 & 47,5 & $+2,5$ & 0,75 \\
\hline 60 & 55 & +5 & 0,75 \\
\hline 70 & 62,5 & $+7,5$ & 0,75 \\
\hline 80 & 70 & +10 & 0,75 \\
\hline
\end{tabular}

\section{Gambar 2. Analisis perekonomian dua sektor}

Hasil analisis dari persamaan 6 dapat formulasikan; fungsi konsumsi $\mathrm{C}=10+0,75 \mathrm{Y}$ apabila besarnya zakat wajib sebesar 2,5\% dan infak-sedekah sebesar 2,5\%, maka:

$$
\mathrm{C}_{\mathrm{i}}=10+(0,75+0,025+0,025) \mathrm{Y}
$$

$\mathrm{C}_{\mathrm{i}}=10+0,80 \mathrm{Y}$ dan fungsi saving Islam adalah $\mathrm{S}_{\mathrm{i}}=-10+0,2 \mathrm{Y}$ pada saat $\mathrm{S}=0$, maka $0=-10+0,2 \mathrm{Y} \rightarrow \mathrm{Y}=50$ dan $\mathrm{Ci}=10+0,8(50) \rightarrow \mathrm{C}_{\mathrm{i}}=50$ dengan mensubsitusikan variabel Zis, maka pada gambar 2 menjadi gambar 3 .

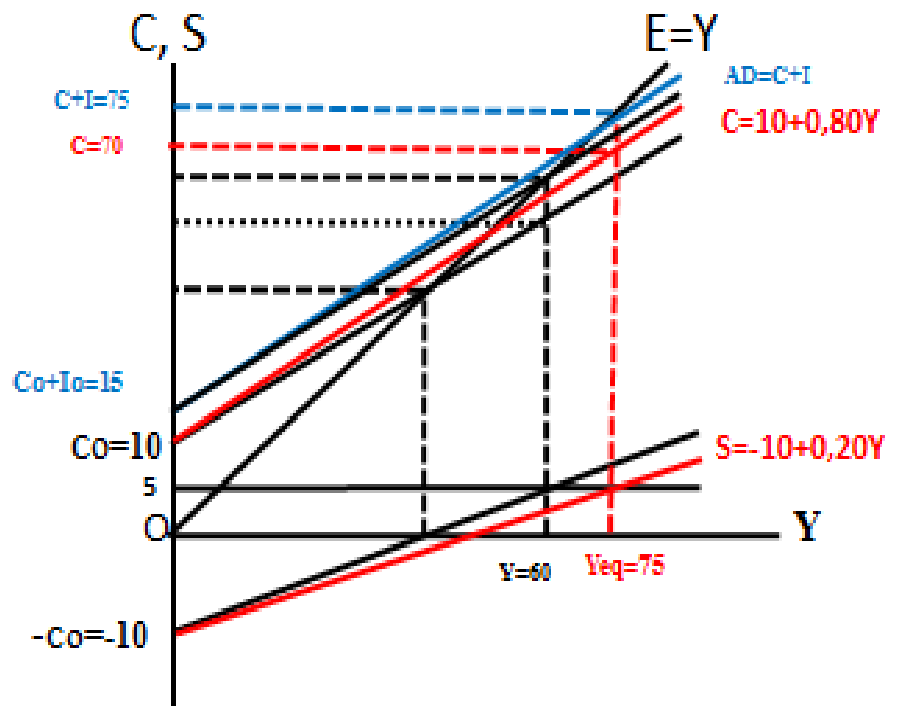

\section{Gambar 3. Dampak Zis terhadap pertumbuhan ekonomi (AD)}

Keadaan pada (i) saat sebelum zakat pendapatan 40 satuan dan setelah zakat menjadi 50 satuan; (ii) posisi sebelum adanya investasi sebesar 5 
satuan sebelum dikomperasikan dengan zakat, maka pendapatan sebesar 60 satuan; (iii) setelah dikomperasikan dengan zakat pendapatan sebesar 75 satuan sehingga pendapatan naik sebesar $(15 / 60) \times 100 \%=25 \%$ dan (iv) terbukti dengan zakat nisab emas zakat wajib 2,5\% dan/atau infak+sedekah 2,5\%, maka menjadi 10 kali lipat hal ini sesuai dengan hadits rasulullah saw; 'setiap satu kebaikan akan digandakan menjadi 10 kali lipat.

Pada perekonomian dua sektor yaitu ditambah dengan investasi I=5 maka diperoleh pendapatan keseimbangan: $\quad \mathrm{I}=\mathrm{S} \quad \mathrm{S}=-10+0,2 \mathrm{Y} \quad 5=-$ $10+0,2 \mathrm{Y} \quad \mathrm{Y}_{\mathrm{ei}}=75$ dan $\mathrm{C}_{\mathrm{ie}}=10+0,8(75) \rightarrow \mathrm{C}_{\mathrm{ie}}=70$. Selengkapnya pada gambar di atas yang mencerminkan dampak zakat, infak dan sedekah terhadap pertumbuhan ekonomi $(\mathrm{Y})$, pada akhirnya $\mathrm{I}+\mathrm{C}=\mathrm{AD}(\mathrm{AD}=$ agregat demand) adalah $5+70=75$ yang menunjukkan hasil akhir dari kontribusi Zis pada AD.

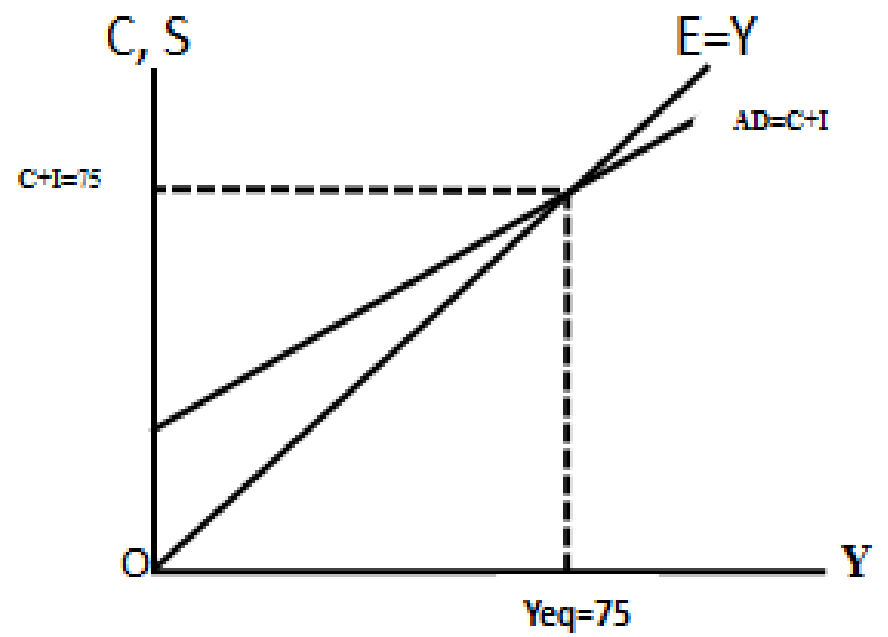

\section{Gambar 4. Kontribusi Zis terhadap pertumbuhan ekonomi}

Keseimbangan antara pendapatan dan pengeluaran ditegaskan pada QS.al-Jumu'ah (62:10) yang mengatakan bahwa: 'apabila shalat telah dilaksanakan, maka bertebarlah kamu di bumi; carilah karunia Allah SWT. dan ingatlah Allah banyak-banyak agar kam beruntung'

Ayat ini Allah mengkaitkan antara peribadatan dengan mencari harta; hal ini mencerminkan bahwa manusia harus mereguk kebahagian duniaakhirat. Dunia mencari harta sebagai pendapatan (Y) dan akherat adalah peduli terhadap orang lain yang dikeluarkan dalam bentuk zakat, infak dan shodaqah sebagai pengeluaran (expenditure, E) sehingga terbentuklan $\mathrm{Y}=\mathrm{E}$, yang pada akhirnya posisi tabungan sama dengan investasi $(S=I)$. Demikian

198| IQTISHODUNA Vol. 16 (2), 2020

http://ejournal.uin-malang.ac.id/index.php/ekonomi 
juga pada ayat adz-daariyaat (49) menyebutkan bahwa; '.... dan segala sesuatu Kami ciptakan berpasang-pasangan supaya kamu mengingat kebesaran Allah'.

Persoalan paling krusial bagi banyak orang adalah bagaimana menyeimbangkan antara pendapatan dengan pengeluaran, karena selamanya kebutuhan lebih besar daripada penghasilan. Menuruti kebutuhan, rasanya tidak akan pernah selesai. Berkaitan dengan hal ini, falsafah lingkaran sangat relevan untuk direnungkan. Lingkaran besar dan lingkaran kecil jika dihitung luasnya tidak ada bedanya, masing-masing 360 derajat. Penghasilan besar dan kecil tidak lagi menjadi persoalan, tetapi yang penting adalah keberkahan dari penghasilan itu.

Keberkahan itu adalah jika apa yang dimiliki dapat bermanfaat untuk memenuhi kebutuhan dan hal itu memberi kebahagiaan di dunia ini dan insya Allah di akhirat kelak. Barakah indikatornya ada tiga yaitu nikmat, sa'adah (kebaikan) dan az-ziyadah yang berarti tambahan, nilai tambah, kebahagiaan, dan sebagainya.

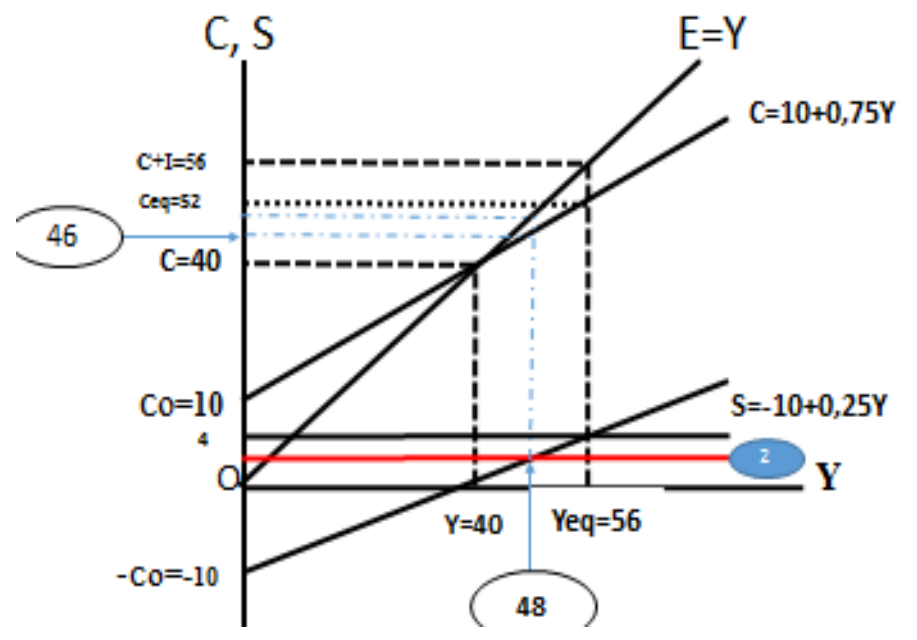

\section{Gambar 5. Pengaruh bunga terhadap pendapatan nasional}

Dimana, (i) apabila I=6-20i (i=10\%), maka I=4, (ii) I=S, I=4 milyar sehingga4=-10+0,25Y(Yeq=56); (iii) apabila bung dinaikkan menjadi 20\%, maka I=2 (garis merah) sehingga; (iv) 2=-10+0,25Y (Yeq=48); (v) Ceq=10+0,75(48)=36 sehingga $\mathrm{Y}=\mathrm{C}+\mathrm{I}=36+2=48$; (iv) Yeq berkurang dari 56 menjadi 48.

Ada 3 sudut pandang (i) individu, yang merupakan 'jembatan' bagi individu dalam rangka memenuhi kebutuhan fitrah serti membeli tanah, rumah untuk menambah kekayaan; (ii) masyarakat yaitu sumberdaya alam yang tersedia yang masih mentah dibutuhkan pengelolaan dengan pikiran 
manusia. Dasar QS.Al-Jatsiyah,45;13); "dan Dia telah menundukkan untukmu apa yang dilangit dan apa yang di bumi semua, (sebagai rahmat) daripadaNya. Sesungguhnya pada yang demikian itu benar-benar terdapat tanda-tanda (kekuasaan Allah) bagi kamu yang berfikir". (Misbah, 2006; Djalaluddin, 2007).

Al-Qur'an menyebut riba diulang 8, diantaranya pada; (i) QS. ar-Rum30:39 menyebutkan ....Dan sesuatu riba (tambahan) yang kamu berikan agar harta manusia bertambah, maka tidak bertambah dalam pandangan Allah. Dan apa yang kamu berikan berupa zakat yang kamu maksudkan untuk memperoleh keridaan Allah, maka itulah orang-orang yang melipat-gandakan (pahalanya); (ii) QS.al-Muddassir-74:6, ...dan janganlah engkau (Muhammad) memberi (dengan maksud) memperoleh (balasan) yang lebih banyak. (iii) QS.al-Baqarah/2:245; QS.Ali 'Imran-3:130; QS.al-Baqarah-2:278-279; QS.alBaqarah/2:275;QS.al-Ma'idah-5:64. Dampak bunga uang akan menyebabkan penuruan terhadap pendapatan (gambar 5).

Antisipasi tanpa menggunakan bunga uang dalam perekonomian dilakukan dengan peningkatan aktivitas ekonomi melalui implementasi 14 transaski syariah. Salah satu diantaranya adalah aplikasi qardhul-hasan pada pelaku ekonomi kreatif makanan siap saji berbasis singkong, yang menunjukkan bahwa akselerasi nilai mata uang saat ini (the value of the currency) dibandingkan nilai yang akan datang (future currency values) dapat diciptakan sebesar 6,7\%-10\% dari sebelumnya. Sebab itulah Zis disamping berdampak positif pada pertumbuhan ekonomi (AD) juga melahirkan keberkahan yang diukur melalui 3 indikator keberkahan, yaitu ni'mah, sa'adah (kebaikan) dan ziyadah (tambahan).

\section{Kesimpulan Dan Saran}

Intruksi variabel Zis berdampak posituif pada agregrat demand (AD) secara sektoral mendorong pertumbuhan ekonomi (Y) baik pada perekonomian. Demikian juga variabel-variabel konsumsi, investasi, saving, pengeluaran pemerintah dan ekspor berdampak positif pada AD. Sedangkan bunga uang berdampak negatif. Antisipasi tanpa menggunakan bunga uang dalam perekonomian dilakukan dengan peningkatan aktivitas ekonomi melalui implementasi 14 transaksi syariah. Salah satu diantaranya adalah aplikasi qardhul-hasan pada pelaku ekonomi kreatif makanan siap saji berbasis singkong, yang menunjukkan bahwa akselerasi nilai mata uang saat ini (the value of the currency) dibandingkan nilai yang akan datang 
(advancedfuture currency values) dapat diciptakan sebesar 6,7\%-10\% dari sebelumnya. Sebab itulah Zis disamping berdampak positif pada pertumbuhan ekonomi (AD) juga melahirkan keberkahan yang diukur melalui 3 indikator keberkahan, yaitu ni'mah, sa'adah (kebaikan) dan ziyadah (tambahan).

Saran pada penelitian ini adalah keseimbangan future currency values bisa diimbangi dengan Zis melalui 14 transaksi syari'ah secara optimal. Kelemahan penelitian dan sekaligus merupakan peluang penelitian (research oppourtunities) adalah; (i) ada 13 transaksi syair'ah ; (ii) perbandingan akselerasi secara pasti antara the value of the currency dan future currency values belum diteli dan (iii) keshohehan 3 indikator keberkahan perlu teruji dan terbukti.

\section{Daftar Pustaka}

Anggraini, R. dan Widiastuti, T. (2017). Penyaluran Dana Zis Dan Tingkat Inflasi Berpengaruh Terhadap Pertumbuhan Ekonomi Indonesia Periode 2011-2015. Jurnal Ekonomi Syariah Teori dan Terapan,. 4(8), 630-641.

Diana, I. N. (2008). Hadits-Hadits Ekonomi. Malang: UIN Malang Press.

Djalaluddin, A. (2007). Manajemen Qur'ani. Menerjemahkan Idarah Ijahiyah dalam Kehidupan. Malang: UIN Press.

Hany, I. H dan Islamiyati, D. (2020). Pengaruh ZIS dan Faktor Makro Ekonomi Terhadap Tingkat Kemiskinan di Indonesia. Jurnal Ekonomi, XXV(1), 118-131.

Masyhuri,M. (2007). Dasar-dasar ekonomi Mikro. Jakarta: Prestasi Pustaka. ISBN: 978-979-1101-29-5. Juni 2007 Edisi I. URL: http://gudangsurat.unisma.ac.id/index.php/s/3JQarC00zm1nz3u --,(2012). Teori Ekonomi Makro. Malang: UIN-Maliki Press. ISBN 978-602-958-426-4.

http://gudangsurat.unisma.ac.id/index.php/s/a8uakZBZISR9Yue -,(2019). Ekonomi Islam. Malang: Media Nusa Creative (MNC). URL: ttp://gudangsurat.unisma.ac.id/index.php/s/NoLHyew0JnEFmTn

Misbahul, M. (2007). Ajaran-Ajaran Ekonomi Rasulullah. Kajian Hadits Nabi dalam Perspektif Ekonomi. Malang: UIN-Press.

Siami-Namini, S. and Hudson, D. (2019). Inflation and income inequality in developed and developing countries. Journal of Economic Studies, 46(3), 611-632.

Tafsir Al-Qur'an Tematik. (2009). Pembangunan Ekonomi Umat. Jakarta: 
Masyhuri

Lajnah Pentashihan Mushaf Al-Qur'an Badan Litbang dan Diklat Kementerian Agama RI. ISBN 978-979-17329-8-7.

(2009). Pemberdayaan Kaum Duhafa. Jakarta: Lajnah

Pentashihan Mushaf Al-Qur'an Badan Litbang dan Diklat Kementerian Agama RI. ISBN 978-979-17329-8-7. 